

\section{Laboratory tests of Draeger Polytron 8000 with FL-6813260 sensor for NH3 measurement}

Roland W. Melse, Johan P.M. Ploegaert, Nico W. M. Ogink

This research was conducted by Wageningen UR Livestock Research, commissioned and funded by the Ministry of Economic Affairs, within the framework of Policy Support Research theme

'Emission reduction' (project number BO-20-0004-049 /BO-20-004-093)

Wageningen UR Livestock Research

Wageningen, August 2016

Livestock Research Report 972 
Melse, Roland W.; Johan P.M. Ploegaert; Nico W. M. Ogink, 2016. Laboratory tests of Draeger Polytron 8000 with $\mathrm{FL}-6813260$ sensor for $\mathrm{NH}_{3}$ measurement. Wageningen UR (University \& Research centre) Livestock Research, Livestock Research Report 972.

http://dx.doi.org/10.18174/388326

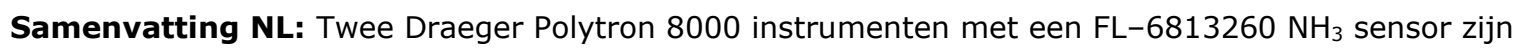
getest in kortdurende laboratoriumexperimenten in het bereik van 0 to $11.0 \mathrm{ppm}$. De meetonzekerheid bleek lager te zijn dan door de fabrikant werd opgegeven. In het gebied van $1-11$ ppm is de nauwkeurigheid van de sensor voldoende hoog om deze toe te passen ten behoeve van emissiemonitoring. In het gebied van $0-1 \mathrm{ppm}$ is echter een grotere nauwkeurigheid nodig om de sensor te kunnen toepassen in natuurlijk geventileerde melkveestallen. De conclusie is dat de sensor een veelbelovende apparaat is voor ammoniakmetingen in en rond stallen, en geschikt is om nader te evalueren onder praktijkomstandigheden. Om de werking van de sensor en de stabiliteit van de kalibratielijnen vast te stellen op de lange termijn en onder praktijkomstandigheden, wordt aanbevolen om de Draeger sensor in een veldstudie nader te testen.

Summary UK: Two Draeger Polytron 8000 instruments with FL-6813260 sensor for $\mathrm{NH}_{3}$ measurement were tested in short-term laboratory experiments in the range from 0 to $11.0 \mathrm{ppm}$. The measurement uncertainty found in the calibration tests was lower than specified by the manufacturer. In the 1-11 ppm range the measurement accuracy is sufficient to meet requirements for emission monitoring. However higher accuracy levels are needed in the 0-1 ppm range to be of interest for application in naturally ventilated cattle barns. It is concluded that the sensor is a promising device for ammonia measurements in and around animal houses, and is suitable for further evaluation under practical conditions. In order to monitor the sensor performance and the stability of calibration lines on long term under barn conditions, it is recommended to test the Draeger sensor in a field study.

(c) 2016 Wageningen UR Livestock Research, P.O. Box 338, 6700 AH Wageningen, The Netherlands, T +31 (0)317 4839 53, E info.livestockresearch@wur.nl, www.wageningenUR.nl/en/livestockresearch. Livestock Research is part of Wageningen UR (University \& Research centre).

All rights reserved. No part of this publication may be reproduced and/or made public, whether by print, photocopy, microfilm or any other means, without the prior permission of the publisher or author.

The ISO 9001 certification by DNV underscores our quality level. All our research commissions are in line with the Terms and Conditions of the Animal Sciences Group. These are filed with the District Court of Zwolle.

Livestock Research Report 972 


\section{Table of contents}

1 $\begin{array}{ll}\text { Introduction } & \mathbf{5}\end{array}$

2

$\begin{array}{ll}\text { Material and Methods } & 7\end{array}$

$\begin{array}{lll}2.1 & \text { Sensors and data processing } & 7\end{array}$

2.2 Experimental setup 8

2.3 Experiment 1: Detection limit and accuracy at low concentrations 8

$\begin{array}{lll}2.4 & \text { Experiment 2: Influence of relative humidity } & 10\end{array}$

3

$\begin{array}{ll}\text { Results and discussion } & 11\end{array}$

3.1 Experiment 1: Detection limit and accuracy at low concentrations 11

3.2 Experiment 2: Influence of relative humidity 16

$\begin{array}{lll}3.3 & \text { Comparability of sensors } & 17\end{array}$

4

Conclusions and recommendations

Appendix A - Certificate of $11.0 \mathrm{ppm} \mathrm{NH}_{3}$ gas cylinder

Appendix B - Certificate of 101 ppm $\mathrm{NH}_{3}$ gas cylinder

Appendix C - Certificates of Signal 821 diluter 



\section{Introduction}

In naturally ventilated cattle houses, ammonia $\left(\mathrm{NH}_{3}\right)$ concentrations in a range of $0.1-3 \mathrm{ppm}{ }^{1}$ can be expected under summer conditions and about $1-6 \mathrm{ppm}$ under winter conditions. In mechanically ventilated pig houses, concentrations can be tenfold. At many pig houses air scrubbers are installed that reduce the ammonia concentrations in the air down to a range of $0.1-3 \mathrm{ppm}$, which is similar to the concentrations that are found in dairy cattle houses in summer.

In the Netherlands a regulatory system is in place which applies an $\mathrm{NH}_{3}$ emission factor to each animal house based on prescribed design and management practices. This means that the actual emissions from the farms are not monitored, although a large variation in emission levels may exist between farms. A similar system with design-based emission factors is used for air scrubbers and in addition several secondary parameters are measured ( $\mathrm{pH}$ and EC of trickling water, electricity use, pressure drop over packing, fresh water use and discharge water amount). These parameters are stored electronically using a so-called obligatory "electronic monitoring system". The values and development of these parameters are used for verifying proper scrubber operation and as a consequence, are used for assessing sufficient ammonia removal performance of the scrubber.

Currently no robust and reliable sensor is available for long-term continuous monitoring of $\mathrm{NH}_{3}$ concentrations in animal houses or air scrubbers at low costs. Especially low concentrations $(<1 \mathrm{ppm})$ and high humidity (outlet scrubber air) make it difficult to operate sensors for a long period (sensor deteriorates fast and frequent zero-calibration is necessary).

However, a suitable sensor that could continuously measure $\mathrm{NH}_{3}$ would enable farmers to real-time monitor the ammonia concentrations in the animal house (e.g. for welfare reasons), the actual emissions from the animal house and the performance of the air scrubber. For monitoring the $\mathrm{NH}_{3}$ emission from an animal house, the $\mathrm{NH}_{3}$ concentration measurement could be combined with a $\mathrm{CO}_{2}$ concentration measurement, the latter enabling an estimation of the air flow rate by means of the $\mathrm{CO}_{2}$-balance method. For monitoring the performance of an air scrubber the $\mathrm{NH}_{3}$ concentration of both inlet and outlet air could be measured.

The German company Draeger has developed a new $\mathrm{NH}_{3}$ sensor that is suitable for a range of 0.5 $100 \mathrm{ppm}$ according to the specifications. Draeger states that this sensor is expected to be suitable for long-term use without the need of regular recalibration (low zero-drift) or other maintenance.

The aim of this study is to carry out a short-term laboratory test of this sensor in order to find out how this sensors performs with regard to detection limit and measurement accuracy, especially at the lower concentrations ( $\leq 11 \mathrm{ppm}$ ). Also the aim is to test whether or not the measurement is influenced by the relative humidity of the air.

This study was funded by the Dutch Ministry of Economic Affairs. The sensors were provided by Draeger at no cost.

\footnotetext{
${ }^{1} 1 \mathrm{ppm} \mathrm{NH} \mathrm{H}_{3}=0.70 \mathrm{mg} / \mathrm{m}^{3}$ at $25^{\circ} \mathrm{C}$ and $1 \mathrm{~atm}$.
} 


\section{$2 \quad$ Material and Methods}

\subsection{Sensors and data processing}

In all experiments two $\mathrm{NH}_{3}$ sensors were used that were connected parallel, generating in duplo measurements.

Sensor name and type: Draeger Polytron 8000 with FL-6813260 sensor for $\mathrm{NH}_{3}$

Main specifications according to manufacturer:

- Working principle: electrochemical diffusion sensor;

- Detection limit: 1 ppm;

- Measurement range limit (max): 100 ppm;

- Calibration: the sensor is factory-calibrated with $\mathrm{NH}_{3}$ and zero gas (2-point calibration);

- Measurement uncertainty: $\leq \pm 5 \%$ of measured value with a minimum of $\leq \pm 1.5 \mathrm{ppm}$ (the greater value applies);

- Operation temperature and relative humidity: $-40 / 65^{\circ} \mathrm{C}$ and $15 / 95 \%$ (although the measurement principle does not require water in the air, Draeger recommends to have an humidity of $>10 \%$ when the sensor is purged constantly, i.e. $>5$ days);

- Air pressure: ambient (1 bar) $\pm 1 \%$;

- Cross references: in Table 1 the known cross-references are given as supplied by the manufacturer;

- Output signal: $4 \ldots 20 \mathrm{~mA}$.

\section{Table 1}

Known cross-references for Draeger $\mathrm{NH}_{3}$ sensor $\mathrm{FL}-6813260$.

\begin{tabular}{|c|c|c|}
\hline Test gas & $\begin{array}{l}\text { Concentration } \\
\text { (ppm) }\end{array}$ & $\begin{array}{l}\mathrm{NH}_{3} \text { sensor reading } \\
(\mathrm{ppm})\end{array}$ \\
\hline $\mathrm{CO}$ & 100 & $<0.5$ \\
\hline $\mathrm{H}_{2} \mathrm{~S}$ & 20 & $<0.8$ \\
\hline $\mathrm{NO}_{2}$ & 10 & $<0.7$ \\
\hline NO & 20 & $<0.5$ \\
\hline $\mathrm{CO}_{2}$ & 16,000 & $<0.5$ \\
\hline $\mathrm{SO}_{2}$ & 20 & -12 \\
\hline $\mathrm{H}_{2}$ & 1,000 & $<0.5$ \\
\hline $\mathrm{Cl}_{2}$ & 10 & -6 \\
\hline $\mathrm{C}_{2} \mathrm{H}_{4}$ & 1,000 & $<0.5$ \\
\hline $\mathrm{HCN}$ & 50 & $<0.5$ \\
\hline $\mathrm{HCl}$ & 5 & $<0.5$ \\
\hline $\mathrm{O}_{3}$ & 0.5 & $<0.5$ \\
\hline $\mathrm{C}_{2} \mathrm{H}_{5} \mathrm{OH}$ & 250 & $<0.5$ \\
\hline $\mathrm{H}_{2} \mathrm{O}_{2}$ & 10 & $<0.5$ \\
\hline Limonene $^{\mathrm{a}}$ & saturated & $<0.5$ \\
\hline Peracetic acid & saturated & $<0.5$ \\
\hline $\mathrm{N}_{2} \mathrm{O}$ & 10,000 & $<0.5$ \\
\hline
\end{tabular}

${ }^{a}$ 1-Methyl-4-(1-methylethenyl)-cyclohexene; ${ }^{\mathrm{b}} \mathrm{CH}_{3} \mathrm{CO}_{3} \mathrm{H}$. 


\section{$2.2 \quad$ Experimental setup}

Two $\mathrm{NH}_{3}$ gas cylinders were used, containing $11.0 \mathrm{ppm}$ and $101 \mathrm{ppm}$ in $\mathrm{N}_{2}$ (Scott Specialty Gases, see certificates in Appendix A and B). The gas from the cylinder was diluted with compressor air using two adjustable gas diluters and led to a measurement chamber were the two $\mathrm{NH}_{3}$ sensors are placed. In Figure 1 a schematic of the setup is given; in Figure 2 both $\mathrm{NH}_{3}$ sensors are shown.

Gas diluter \#1 is a Signal Model 821 Gas Divider, which has an adjustable dilution ratio up to $1: 10$. The dilution ratio is set with percentages ranging from $10 \%$ (i.e. $10 \%$ source gas is mixed with $90 \%$ of compressed air, so $10 \times$ dilution) to $100 \%$ (i.e. $100 \%$ source gas without compressed air, no dilution). If necessary, a second gas diluter (\#2) was connected in series. Gas diluter \#2 is an EPM Diluting Stack Sampler, diluting unit 797-430, adjustable dilution ratio) which was operated at a dilution ratio of 1 : 18.65 (at a pressure of 6.0 bar). In Appendix $C$ and $D$ the calibration reports from both gas diluters are given In one experiment a humidifier was connected in order to increase the humidity of the air prior to reaching the $\mathrm{NH}_{3}$ sensors. The humidifier consisted of a bottle with at the bottom a small amount of water (net air volume of bottle, incl. extra tubing: $380 \mathrm{ml}$ ). The bottle is placed in a thermostat bath. Through the lid of the bottle an inlet and outlet tube are inserted; the inlet tube is close to the water level but does not touch it, the outlet tube is close to the top of the bottle. By increasing the temperature of the bath, the humidity of the air increases. Before reaching the sensors, the humidity and temperature of the air are measured (Vaisala, Finland; HMP 110). Then the air reaches a chamber where the $\mathrm{NH}_{3}$ concentrations are measured with the two Draeger Polytron 8000 FL-6813260 sensors. With a precision resistor of $50 \Omega$ (Neohm UPW-50, $\pm 0.1 \%, 3 \times 10-6 \Omega /{ }^{\circ} \mathrm{C}$ ) the 4 - $20 \mathrm{~mA}$ output signal of the sensors was converted to a 200 - $1000 \mathrm{mV}$ signal that was recorded every 10 seconds with a data logger (Campbell Scientific Inc., Logan UT, USA; type CR1000). The resolution of the data logger is $0.1 \mathrm{mV}$ (i.e. $0.0125 \mathrm{ppm}$ ) for values between 200 and $800 \mathrm{mV}$ (i.e. 0 $75 \mathrm{ppm}$ ) and $1 \mathrm{mV}$ (i.e. $0.125 \mathrm{ppm}$ ) for values above $800 \mathrm{mV}$ (i.e. $>75 \mathrm{ppm}$ ). Eventually the measurement by the Draeger sensors are converted to ppm's by assuming $4 \mathrm{~mA}$ is equal to $0 \mathrm{ppm}$ and $20 \mathrm{~mA}$ is equal to $100 \mathrm{ppm}$, in accordance with the specifications of the sensor.

All tubing was made of FEP in order to prevent absorption of ammonia. The experiments were carried out at room temperature $\left(20-23^{\circ} \mathrm{C}\right)$ and at atmospheric pressure $(1015-1022 \mathrm{hPa})$; the gas temperature at the sensors was slightly higher $\left(23-25^{\circ} \mathrm{C}\right)$. During the experiments no condensation was observed in the tubing or in the measurement chamber.

Prior to the experiments the used equipment was checked and calibrated:

- the data logger values were checked and calibrated with a calibrated voltmeter (Fluke, type 87III);

- the value of the precision resistors were checked with a calibrated voltmeter (Fluke, type 87III);

- the gas dilution ratio of both gas diluters was based on available certificates and checked using a chemiluminescent $\mathrm{NO}_{x}$ analyser (Monitor Labs / API, model $200 \mathrm{~A}$ ) and a cylinder of NO gas (Scott Specialty Gases, 40 ppm).

\subsection{Experiment 1: Detection limit and accuracy at low concentrations}

In this experiment a range of $\mathrm{NH}_{3}$ concentrations between 0 en $11 \mathrm{ppm}$ was supplied to the $\mathrm{NH}_{3}$ sensors, using different gas cylinders and diluter settings. The humidification unit was switched off. Table 2 explains how the different $\mathrm{NH}_{3}$ concentrations were generated. Also a zero $\mathrm{ppm} \mathrm{NH}_{3}$ test was done by supplying pure compressed air to the sensors. Each concentration was supplied for about 15 minutes in which period a stable signal could be established. During these experiments the relative humidity was $3-5 \%$ and the temperature $23-25^{\circ} \mathrm{C}$.

The concentration level that was supplied at the sensors was calculated based on the gas diluter settings and the source gas concentration. 


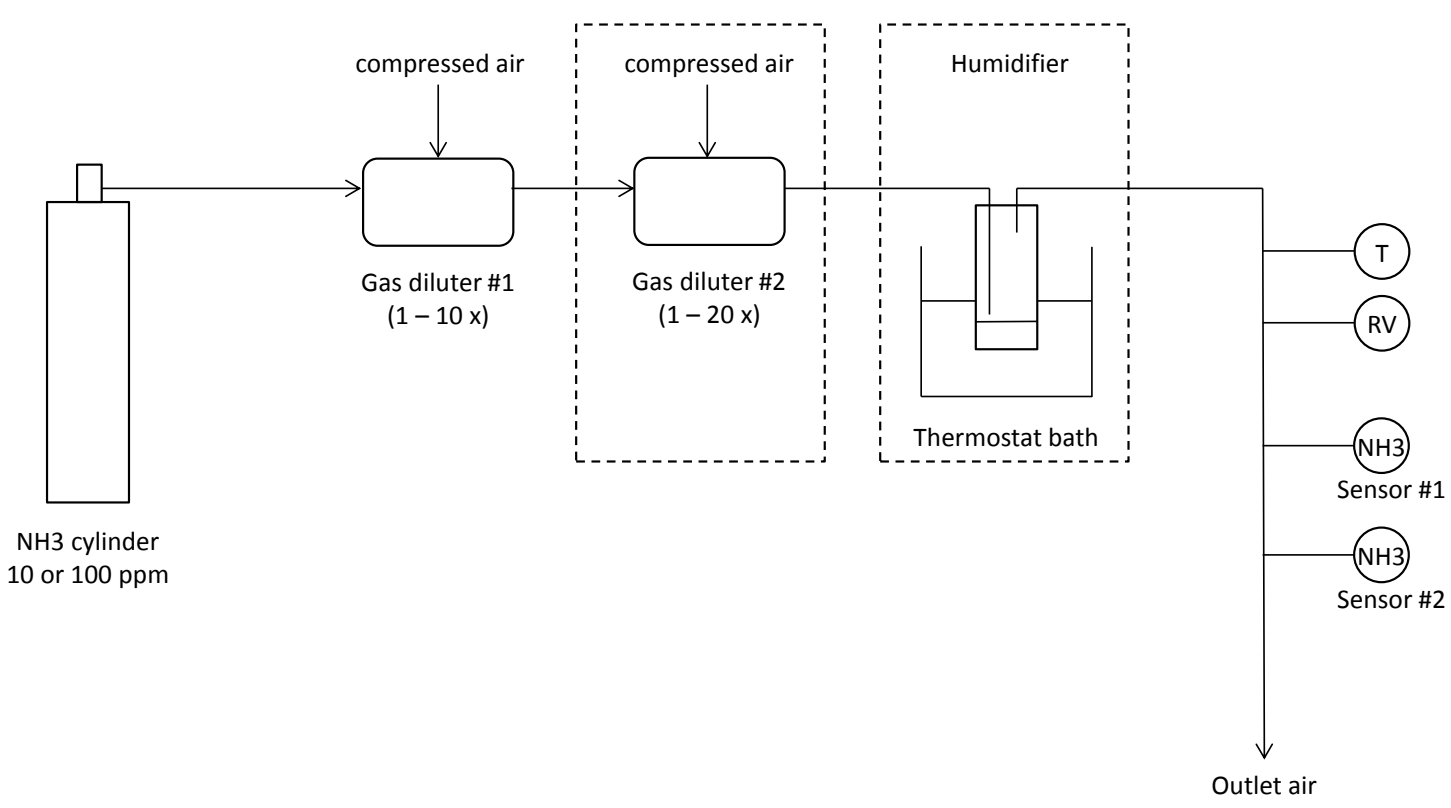

Figure 1 Schematic of laboratory setup for testing the $\mathrm{NH}_{3}$ sensors.

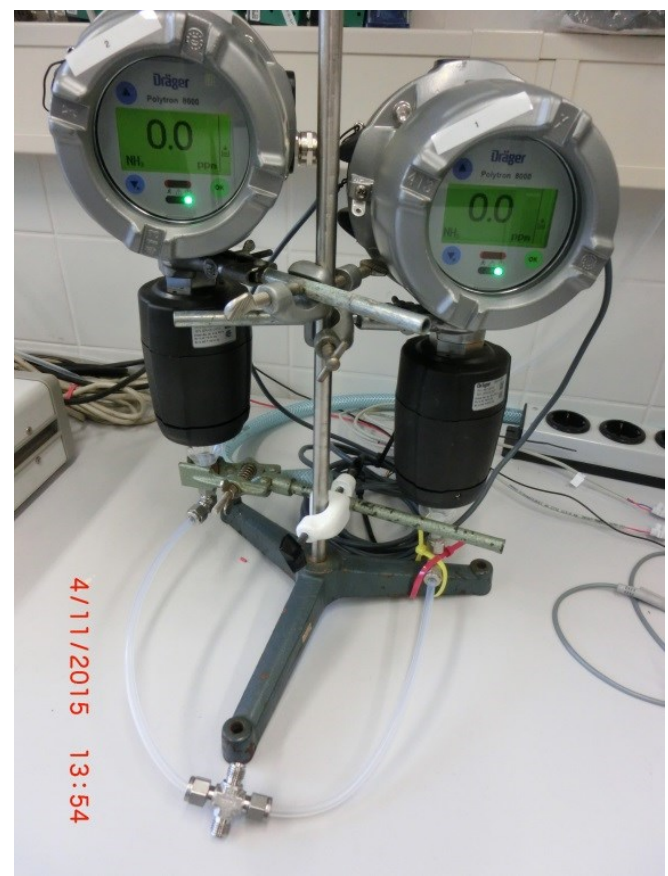

Figure 2 Picture of the two $\mathrm{NH}_{3}$ sensors. 


\section{Table 2}

Test concentrations of $\mathrm{NH}_{3}$ - low concentration range $(0-11$ ppm); n.a. = not applicable.

\begin{tabular}{|c|c|c|c|c|}
\hline $\begin{array}{l}\text { Source } \mathrm{NH}_{3} \text { gas } \\
(\mathrm{ppm})\end{array}$ & $\begin{array}{c}\text { Gas diluter \#1 } \\
\qquad \begin{array}{c}\%) \\
\text { SIGNAL }\end{array}\end{array}$ & $\begin{array}{c}\text { Gas diluter \#1 } \\
\text { (times diluted) } \\
\text { SIGNAL }\end{array}$ & $\begin{array}{c}\text { Gas diluter \#2 } \\
\text { (times diluted) } \\
\text { EPM } 6.0 \text { bar }\end{array}$ & $\begin{array}{l}\text { Supplied } \mathrm{NH}_{3} \text { at } \\
\text { sensors }(\mathrm{ppm})\end{array}$ \\
\hline 0 & n.a. & n.a. & n.a. & 0 \\
\hline 11.0 & 10 & 9.95 & 18.65 & 0.06 \\
\hline 11.0 & 20 & 5.02 & 18.65 & 0.12 \\
\hline 11.0 & 40 & 2.52 & 18.65 & 0.23 \\
\hline 11.0 & 80 & 1.25 & 18.65 & 0.47 \\
\hline 11.0 & 100 & 1.00 & 18.65 & 0.59 \\
\hline 11.0 & 10 & 9.95 & n.a. & 1.11 \\
\hline 11.0 & 20 & 5.02 & n.a. & 2.19 \\
\hline 11.0 & 30 & 3.35 & n.a. & 3.28 \\
\hline 11.0 & 40 & 2.52 & n.a. & 4.37 \\
\hline 11.0 & 50 & 2.00 & n.a. & 5.49 \\
\hline 11.0 & 80 & 1.25 & n.a. & 8.79 \\
\hline 11.0 & 100 & 1.00 & n.a. & 11.0 \\
\hline
\end{tabular}

\subsection{Experiment 2: Influence of relative humidity}

In this experiment a selection of $\mathrm{NH}_{3}$ concentrations was fed to the $\mathrm{NH}_{3}$ sensors, using the humidification unit to establish different humidity levels of the gas. Gas diluter \#2 was switched off. In Table 3 the testing conditions are further explained. Also a zero $\mathrm{ppm} \mathrm{NH}_{3}$ test was done by supplying pure compressed air to the sensors. Each concentration was supplied for about 15 minutes in which period a stable signal could be established. During these experiments the temperature was $23-25^{\circ} \mathrm{C}$.

\section{Table 3}

Test concentrations of $\mathrm{NH}_{3}$ at low relative humidity (3-5\%), medium (40-50\%), and high relative humidity (70-80\%); n.a. = not applicable.

\begin{tabular}{cccc} 
Source $\mathrm{NH}_{3}$ gas $(\mathrm{ppm})$ & $\begin{array}{c}\text { Gas diluter \#1 } \\
(\%)\end{array}$ & $\begin{array}{c}\text { Gas diluter \#1 } \\
\text { (times diluted }) \\
\text { SiGNAL }\end{array}$ & $\begin{array}{c}\text { Supplied } \mathrm{NH}_{3} \text { at } \\
\text { sensors }(\mathrm{ppm})\end{array}$ \\
\hline 0 & n.a. & n.a. & 0 \\
\hline 11.0 & 10 & 9.95 & 1.11 \\
\hline 11.0 & 50 & 2.00 & 5.49 \\
\hline 101 & 10 & 9.95 & 10.2 \\
\hline
\end{tabular}




\section{Results and discussion}

\subsection{Experiment 1: Detection limit and accuracy at low concentrations}

In Table 4 the results of experiment 1 are shown, after stabilization of the output signal of the sensors for at least 5 minutes. The "supplied $\mathrm{NH}_{3}$ concentration" is the concentration as calculated from the source gas and the dilution equipment settings. After the concentration was increased, after about 3 minutes a stable output signal was achieved. Within the experimental setup that was chosen it is not possible to distinguish between the time that is needed to reach the desired concentration in the air present at the sensors (as it is no perfectly mixed system), or the time that is needed by the sensors to respond to a step increase or decrease of ammonia concentration of the air supplied to the sensor.

Table 4

Results of $\mathrm{NH}_{3}$ measurements with electrochemical diffusion sensors - low concentration range (temperature: $23-25^{\circ} \mathrm{C}$; relative humidity: $3-5 \%$ ); n.d. = not detected.

\begin{tabular}{ccc} 
Supplied $\mathrm{NH}_{3}$ concentration & Measured $\mathrm{NH}_{3}$ concentration $(\mathrm{ppm})$ \\
$(\mathrm{ppm})$ & Sensor \# & Sensor \#2 \\
0 & -0.19 & -0.18 \\
\hline .06 & n.d. & n.d. \\
\hline 0.12 & n.d. & n.d. \\
\hline 0.23 & -0.025 & 0.068 \\
\hline 0.47 & 0.31 & 0.41 \\
\hline 0.59 & 0.40 & 0.49 \\
\hline 1.11 & 1.15 & 1.24 \\
\hline 2.19 & 2.25 & 2.35 \\
\hline 3.28 & 3.43 & 3.53 \\
\hline 4.37 & 4.69 & 4.76 \\
\hline 5.49 & 5.78 & 6.04 \\
\hline 8.79 & 9.14 & 9.40 \\
\hline 11.0 & 11.25 & 11.68 \\
\hline
\end{tabular}

For the tested concentrations of 0.06 and $0.12 \mathrm{ppm}$, no increase of the $\mathrm{mA}$ output signal of the sensors was detected, therefore these values are reported as "not detected". As can be seen for the 0 ppm value (and for the $0.23 \mathrm{ppm}$ value for sensor \#1) slightly negative measured ppm values were found, i.e. the output signal was slightly lower than $4 \mathrm{~mA}$. From Table 4 it follows that both sensors overestimate the supplied $\mathrm{NH}_{3}$ at values between 1.11 and $11.0 \mathrm{ppm}$, and underestimate at concentrations of $0.59 \mathrm{ppm}$ and lower.

In Figure 3 the results of Table 4 are plotted, together with a linear regression line for each sensor. This regression line can be considered as the calibration line to be used for each sensor. Furthermore, the line $Y=X$ is shown. The regression lines can be formulated as ( $2=$ coefficient of determination; RSD = Residual Standard Deviation):

\section{Sensor \# 1:}

Measured $\left[\mathrm{NH}_{3}\right](\mathrm{ppm})=$ Supplied $\left[\mathrm{NH}_{3}\right](\mathrm{ppm}) \times 1.0506-0.1143$

[R2 = 0.9989; RSD = 0.137] 


\section{Sensor \#2:}

Measured $\left[\mathrm{NH}_{3}\right](\mathrm{ppm})=$ Supplied $\left[\mathrm{NH}_{3}\right](\mathrm{ppm}) \times 1.0803-0.0691$

$[R 2=0.9993 ; R S D=0.113]$

The concentration that can be calculated using these calibration lines and the measured values, is called the predicted concentration.

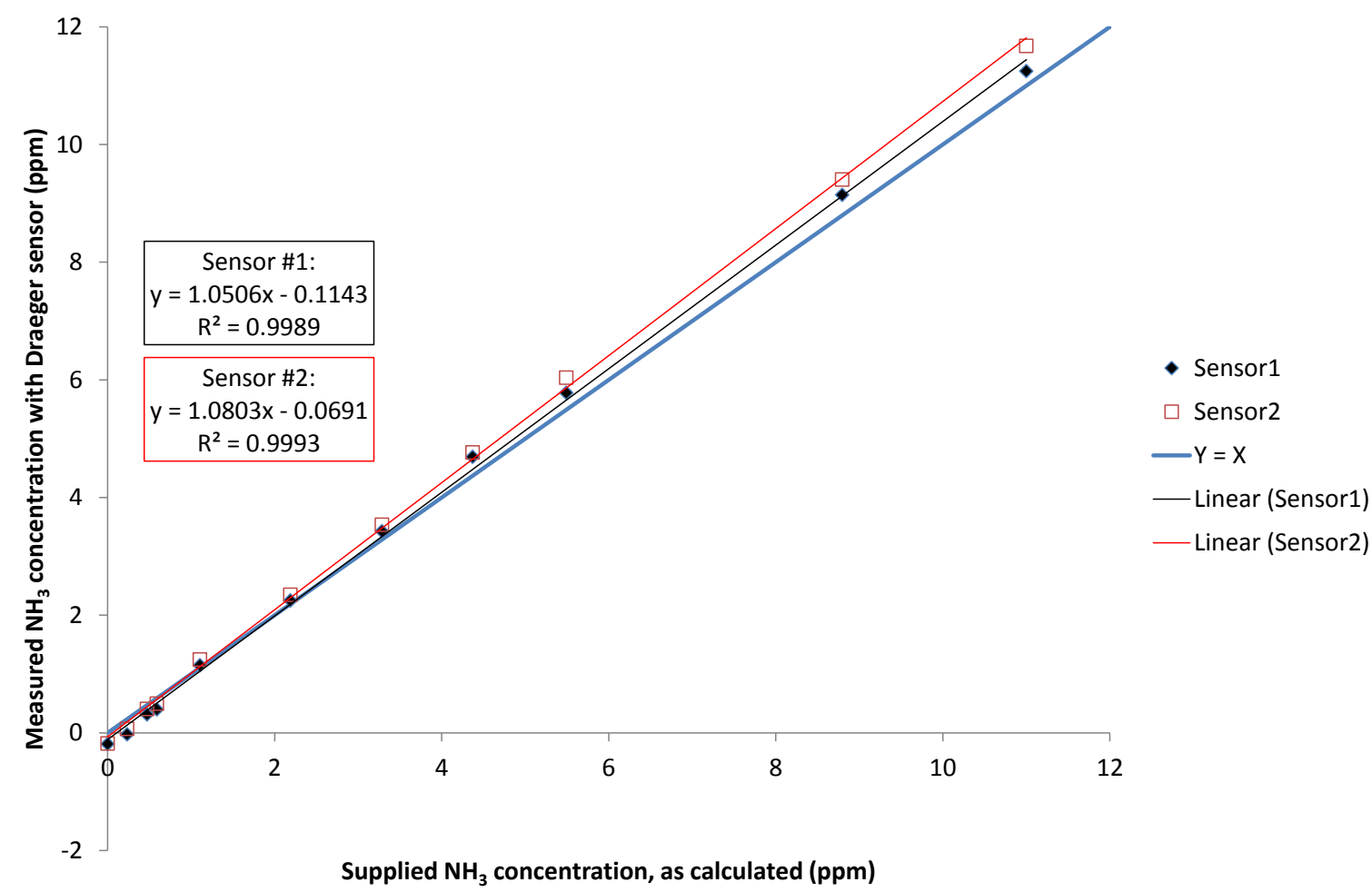

Figure 3 Measured $\mathrm{NH}_{3}$ concentration versus supplied $\mathrm{NH}_{3}$ concentration for both Draeger sensors $(R V=3-5 \%)$.

When the measurement signal (in $\mathrm{mA}$ ) is used as input variable and the supplied $\mathrm{NH}_{3}$ concentration as output, the following equations can be formulated:

\section{Sensor \#1:}

Supplied $\left[\mathrm{NH}_{3}\right](\mathrm{ppm})=$ Measurement signal $(\mathrm{mA}) \times 5.9425-23.658$

$[R 2=0.9989 ; R S D=0.13]$

\section{Sensor \#2:}

Supplied $\left[\mathrm{NH}_{3}\right](\mathrm{ppm})=$ Measurement signal $(\mathrm{mA}) \times 5.7813-23.059$

$[R 2=0.9991 ; R S D=0.10]$

In Figure 4 the residuals are shown, i.e. the deviations between supplied and the predicted concentrations. Figure 4 clearly shows that residuals are not evenly distributed over the whole concentration range. In the range $<1 \mathrm{ppm}$ the predicted concentrations are lower than the supplied concentrations (positive residual values) and in the range $1-6 \mathrm{ppm}$ the predicted concentrations are higher than the supplied concentrations (negative residual values). The highest measurements then show positive residual values) again. The residuals show that the sensors do no respond rectilinear in the offered concentration range. For this reason the calibration lines and residual values were calculated when the concentration range is split into a $0-1 \mathrm{ppm}$ and a $1-11 \mathrm{ppm}$ range; this is shown in Figure 5 and 6 for Sensor \#1 and \#2, respectively. 


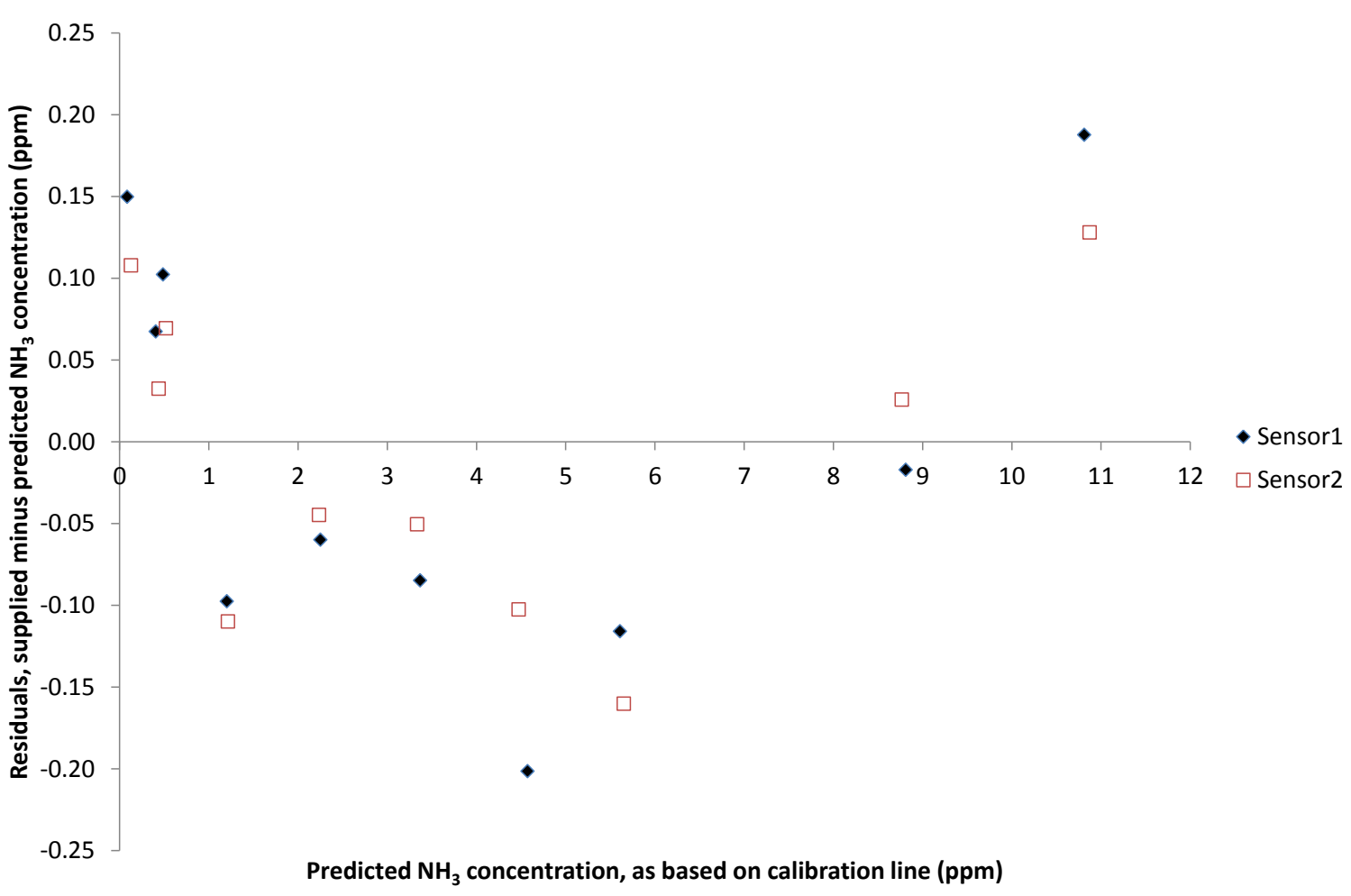

Figure 4 Residual values (i.e. supplied minus predicted $\mathrm{NH}_{3}$ concentration) for both Draeger sensors $(R V=3-5 \%)$.

The regression lines shown in Figure $5 a$ and $6 a$ can be formulated as follows:

0 - 1 ppm, Sensor \# 1:

Measured $\left[\mathrm{NH}_{3}\right](\mathrm{ppm})=$ Supplied $\left[\mathrm{NH}_{3}\right](\mathrm{ppm}) \times 1.2336-0.2636$

$[R 2=0.9858 ; R S D=0.071]$

0 - 1 ppm, Sensor \#2:

Measured $\left[\mathrm{NH}_{3}\right](\mathrm{ppm})=$ Supplied $\left[\mathrm{NH}_{3}\right](\mathrm{ppm}) \times 1.2958-0.2168$

[R2 = 0.9954; RSD = 0.042]

1 - 11 ppm, Sensor \# 1:

Measured $\left[\mathrm{NH}_{3}\right](\mathrm{ppm})=$ Supplied $\left[\mathrm{NH}_{3}\right](\mathrm{ppm}) \times 1.0247+0.0781$

[R2 = 0.9994; RSD = 0.096]

\section{1 - 11 ppm, Sensor \# 2:}

Measured $\left[\mathrm{NH}_{3}\right](\mathrm{ppm})=$ Supplied $\left[\mathrm{NH}_{3}\right](\mathrm{ppm}) \times 1.0585+0.0921$

[R2 = 0.9997; RSD = 0.076]

In this way for measurements in the range of $0-1 \mathrm{ppm}$ the first regression line can be used for calibration, while in the range of $1-11 \mathrm{ppm}$ the second regression line can be used. 


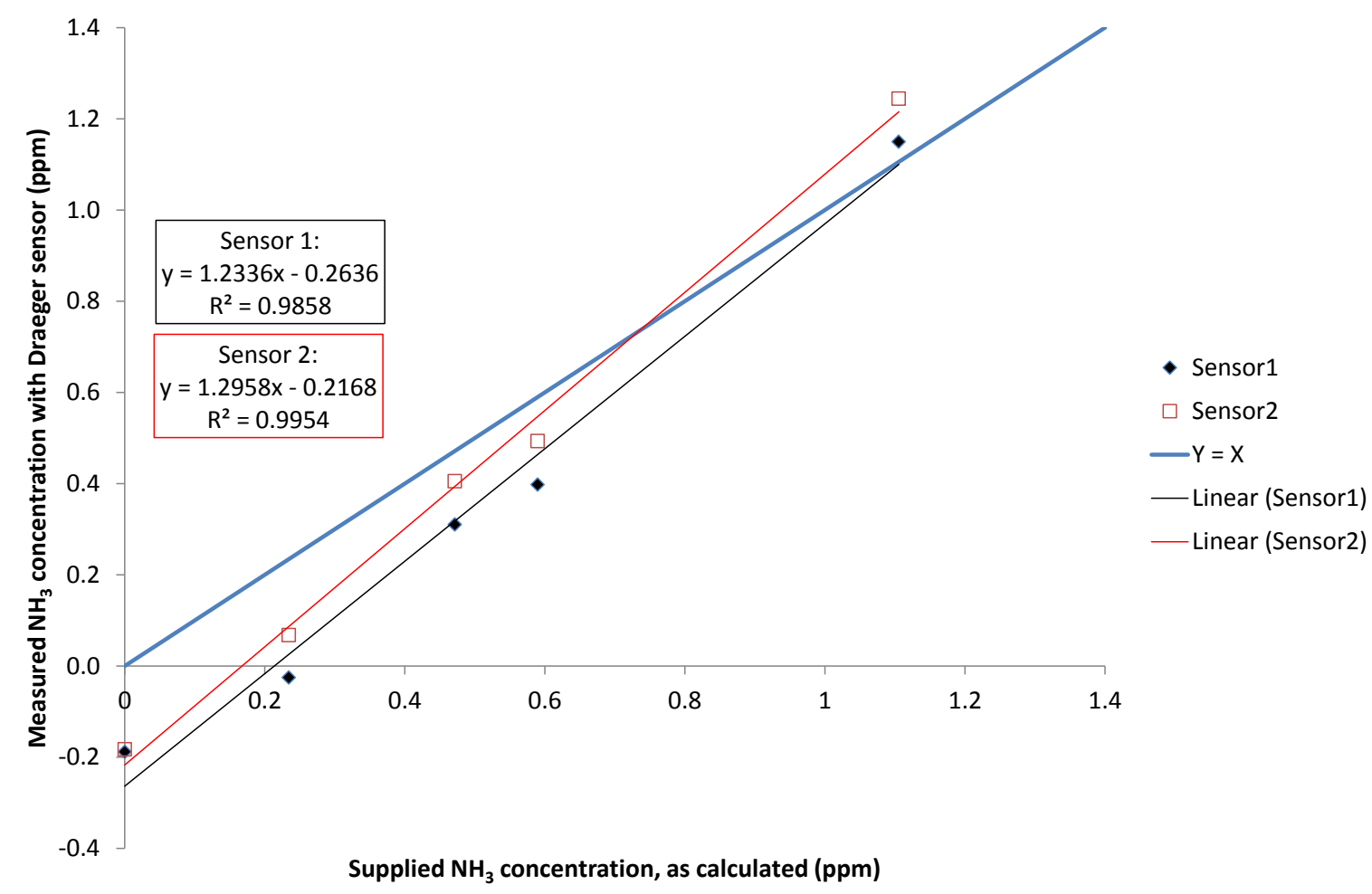

Figure 5a Measured $\mathrm{NH}_{3}$ concentration versus supplied $\mathrm{NH}_{3}$ concentration for both Draeger sensors, range of $0-1 \mathrm{ppm}(\mathrm{RV}=3-5 \%)$.

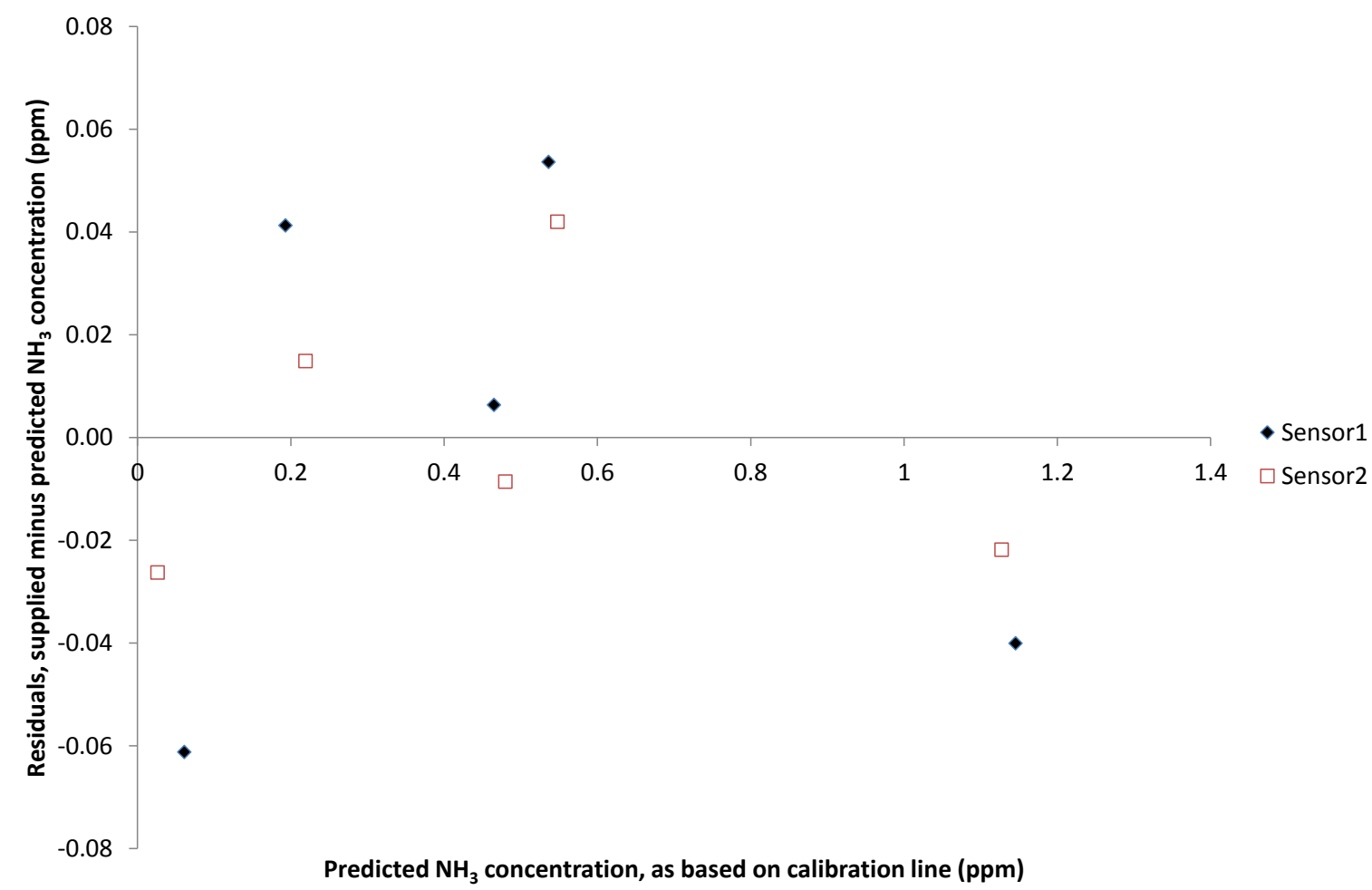

Figure 5b Residual values (i.e. supplied minus predicted $\mathrm{NH}_{3}$ concentration) for both Draeger sensors, range of $0-1 \mathrm{ppm}(\mathrm{RV}=3-5 \%)$. 


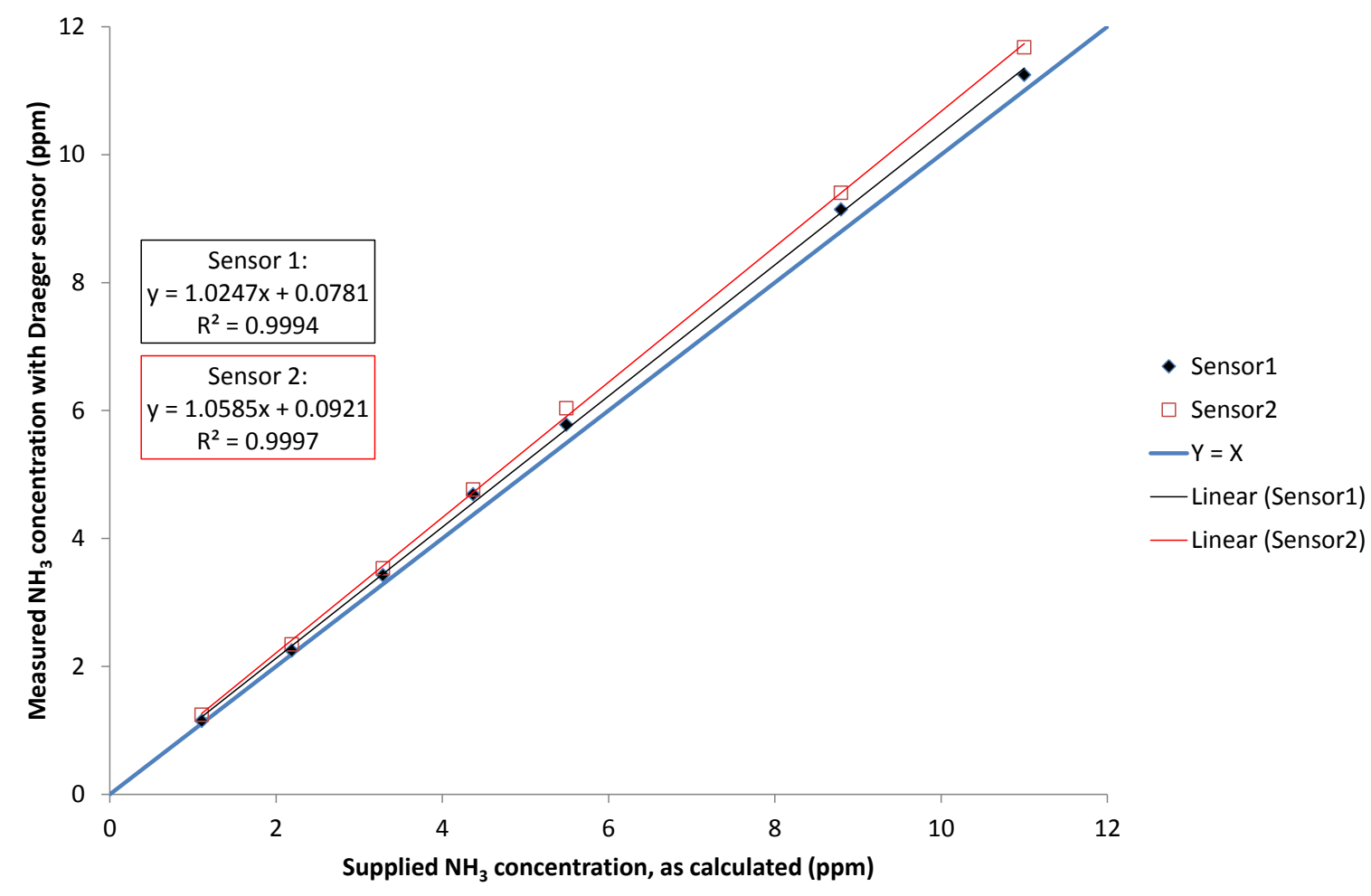

Figure 6a Measured $\mathrm{NH}_{3}$ concentration versus supplied $\mathrm{NH}_{3}$ concentration for both Draeger sensors, range of $1-11 \mathrm{ppm}(R \mathrm{~V}=3-5 \%)$.

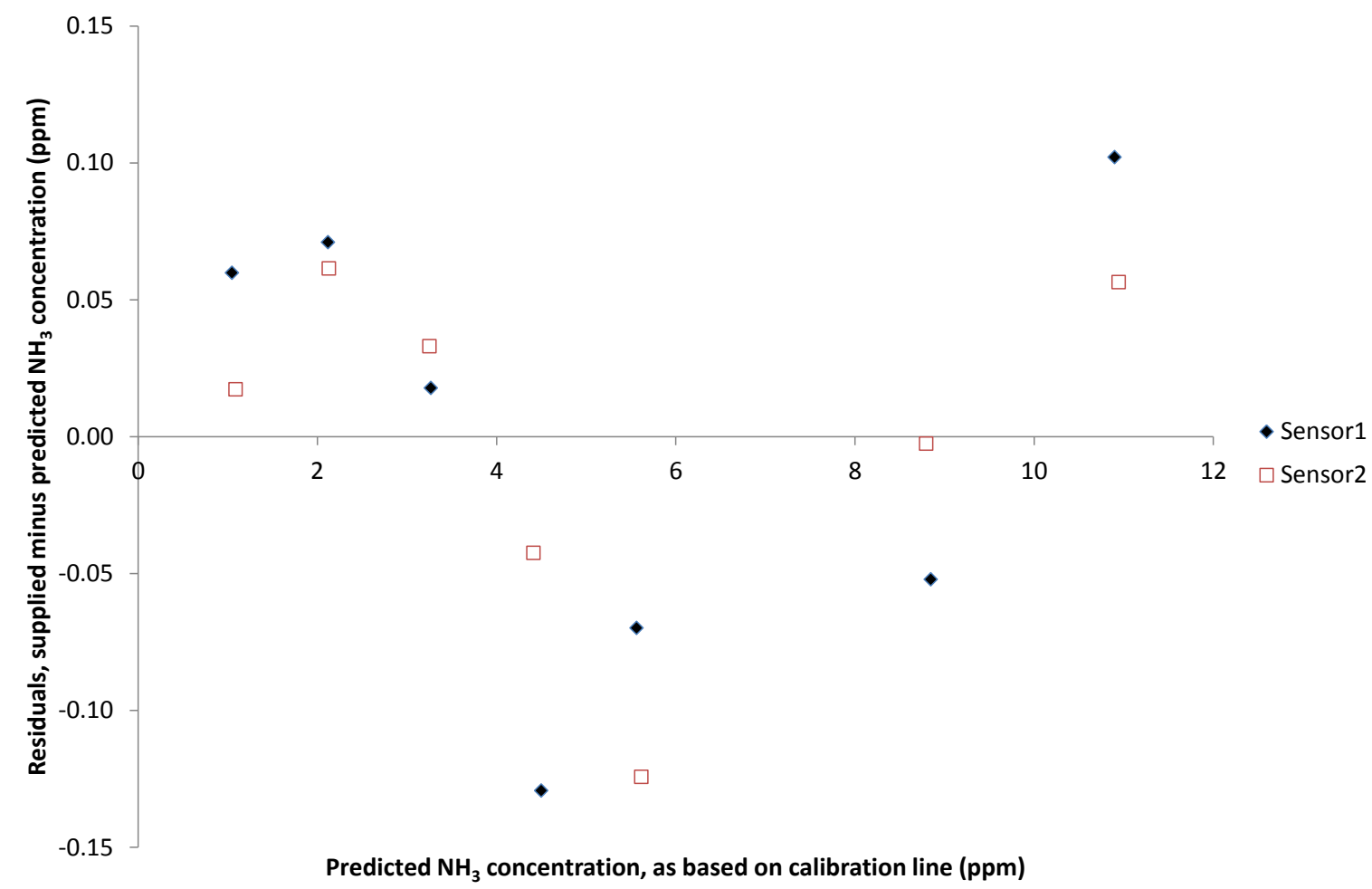

Figure $6 \boldsymbol{b}$ Residual values (i.e. measured $\mathrm{NH}_{3}$ concentration minus predicted $\mathrm{NH}_{3}$ concentration) for both Draeger sensors, range of 1 - 11 ppm (RV = 3-5\%). 
Comparison of the residual values in Figure 4 (whole range) with Figure $5 \mathrm{~b}(0-1 \mathrm{ppm})$ and Figure $6 \mathrm{~b}$ $(1-11 \mathrm{ppm})$ shows that the residual values decrease when a different calibration curve is used for the low and the high range concentrations. This means that more accurate measurements can be done.

\subsection{Experiment 2: Influence of relative humidity}

In Table 5 the results of experiment 2 are shown, after stabilization of the output signal of the sensors.

\section{Table 5}

Results of $\mathrm{NH}_{3}$ measurements with electrochemical diffusion sensors at different humidity levels (temperature: $23-25^{\circ} \mathrm{C}$ ); n.a. = not applicable.

\begin{tabular}{cccc} 
Relative humidity & $\begin{array}{c}\text { Supplied } \mathrm{NH}_{3} \\
\text { concentration }(\mathrm{ppm})\end{array}$ & $\begin{array}{c}\text { Measured } \mathrm{NH}_{3} \text { concentration }(\mathrm{ppm}) \\
\text { Sensor \# }\end{array}$ & $\begin{array}{c}\text { Sensor \#2 } \\
\text { 3-5 (low) }\end{array}$ \\
& 0 & -0.10 & -0.18 \\
& 1.11 & 1.15 & 1.24 \\
& 5.49 & 5.78 & 6.04 \\
& 10.2 & 10.6 & -0.020 \\
\hline 40-50 (medium) & 0 & -0.103 & 1.24 \\
& 1.11 & 1.15 & 6.12 \\
& 5.49 & 5.95 & 11.1 \\
\hline $70-80$ (high) & 10.2 & 10.7 & 0.068 \\
& 0 & 0.045 & 1.49 \\
& 1.11 & 1.41 & 6.20 \\
& 5.49 & 5.98 & 11.7 \\
\hline
\end{tabular}

In Figure 7 the average measurement values of the sensors are plotted against the supplied $\mathrm{NH}_{3}$ concentration for all RV ranges, together with a linear regression line. The regression line for low RV $(3-5 \%)$ is the calibration line that was presented already in section 3.1. Figure 7 clearly shows that the sensors show higher readings at higher humidity levels, as the lines for medium RV (black) and high RV (red) are above the line for low RV (blue).

Furthermore, in this experiment it took more time for the sensors to stabilize than in Experiment 1 , in some cases up to 25 minutes; in Experiment 1 the time needed for stabilization was only about 3 minutes. This delay is caused by the fact that by connecting the bottle for humidification, the gas volume of the measurement system is largely increased. As a result, the time that is needed to reach the desired concentration in the air present at the sensors increases (as it is no perfectly mixed system), thus ending up in a slower responses to concentration changes. 


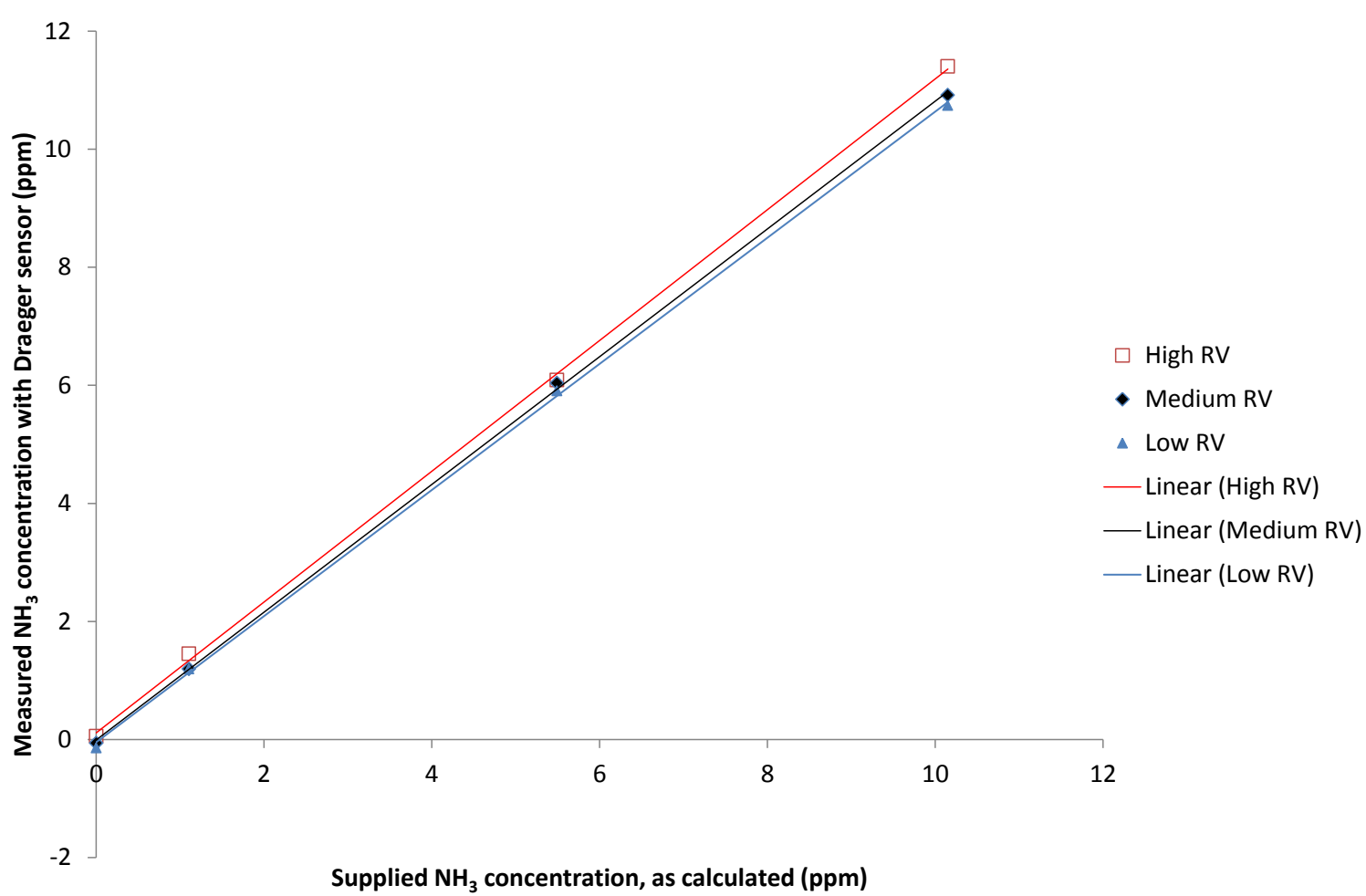

Figure 7 Measured $\mathrm{NH}_{3}$ concentration versus supplied $\mathrm{NH}_{3}$ concentration (average of both Draeger sensors) at different humidity levels.

\subsection{Comparability of sensors}

To test the comparability of the results the two different $\mathrm{NH}_{3}$ sensors were exposed simultaneously to the same polluted air, and the response of the devices to the provided concentration was registered, as described. This test was repeated at different ammonia concentration levels and different relative humidity levels. Then, the dataset with the paired results from the devices was analysed for outliers by using the box plot method with three times the interquartile range (IQR) as measure for extreme outliers:

$\mathrm{IQR}=\mathrm{Q} 3-\mathrm{Q} 1$

Q1: lower (first) quartile (25\%)

Q2: median (second quartile)

Q3: upper (third) quartile (75\%)

Outlier if: value $>$ Q3+3*IQR OR value $<$ Q1-3*IQR

This test shows that devices are giving not comparable results at the low concentration levels, i.e. measured concentrations $\leq 0.5 \mathrm{ppm}$ (supplied concentration: $\leq 0.59 \mathrm{ppm}$ ), as all results in this range were found to be outliers. For measured concentrations at and above $1.2 \mathrm{ppm}$ (supplied concentration $\geq 1.11 \mathrm{ppm}$ ), no outliers were found. Figure $8 \mathrm{a}$ also shows a (small) systematic difference $(4 \%)$ between both devices. The observed difference between devices is independent of the provided $\mathrm{NH}_{3}$ concentration level (Figure 8b). 

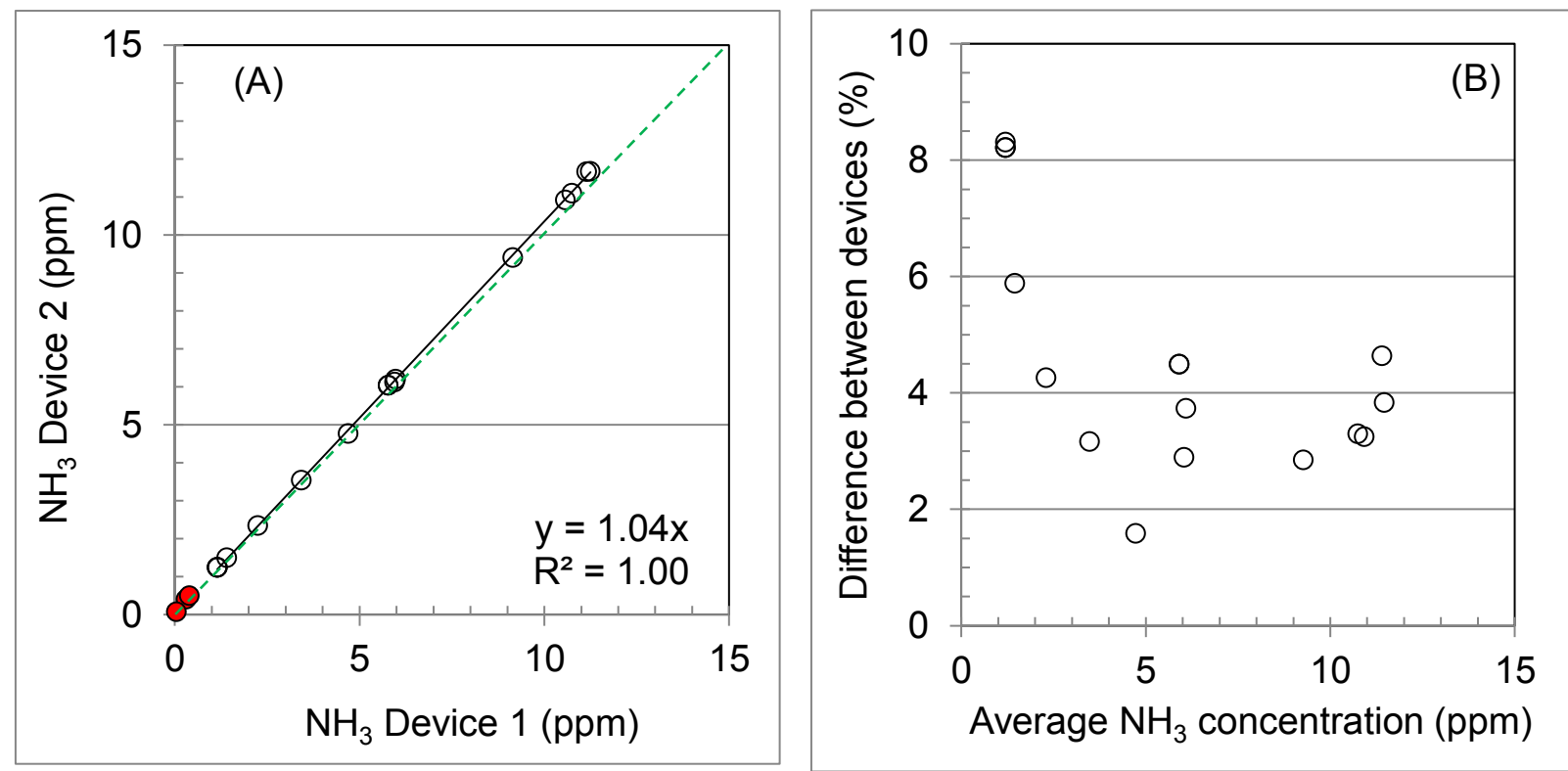

Figure 8 Comparability of results between devices. (A) Absolute measured values; red dots are the points considered as outliers in the box plot method; (B) Difference between devices vs. average $\mathrm{NH}_{3}$ concentration. 


\section{Conclusions and recommendations}

Two Draeger Polytron 8000 instruments with FL-6813260 sensor for $\mathrm{NH}_{3}$ measurement were tested in short-term laboratory experiments in the range from 0 to $11.0 \mathrm{ppm}$. The results showed that the response of the sensor was not fully rectilinear in this range, and that calibration with a linear model is best applied separately at the $0-1 \mathrm{ppm}$ range and the $1-11 \mathrm{ppm}$ range.

The mean residual standard deviation of the $0-1 \mathrm{ppm}$ calibration line amounted $0.056 \mathrm{ppm}$. Estimating an uncertainty interval, as an approximation, on two times the standard deviation this would result in an uncertainty interval of $\pm 0.11 \mathrm{ppm}$. Expressed as a relative error of the median value of $0.5 \mathrm{ppm}$ in this range, the relative error here would amount $23 \%$. At values in the 1-11 ppm range the residual standard deviation amounted $0.086 \mathrm{ppm}$, resulting in an uncertainty interval of $0.17 \mathrm{ppm}$, and a relative error at the median value of $6 \mathrm{ppm}$ of $2.8 \%$. In both intervals we assume that no systematic errors are present because bias is corrected on basis of the regression lines. Our test setup was not suited to evaluate drift from the calibration lines, hence estimated uncertainties represent a best case scenario.

Nevertheless the results give the impression that in the 1-11 ppm range the accuracy is better than expected from the specifications of the manufacturer (Specified measurement uncertainty: $\leq \pm 5 \%$ of measured value with a minimum of $\leq \pm 1.5 \mathrm{ppm}$, where the greater value applies). In the $0-1 \mathrm{ppm}$ range the measurement uncertainty amounted $\pm 0.11 \mathrm{ppm}$, being considerably lower than the specified minimum of $\leq \pm 1.5 \mathrm{ppm}$.

Also, the influence of humidity was tested. The measured $\mathrm{NH}_{3}$ concentration slightly increased at higher humidity levels.

It is concluded from the laboratory test that this Draeger sensor is a promising device for ammonia measurements in and around animal houses, and is suitable for further evaluation under practical conditions. The measurement uncertainty found in the calibration tests was lower than specified by the manufacturer. In the 1-11 ppm range the measurement accuracy is sufficient to meet requirements for emission monitoring. However higher accuracy levels are needed in the 0-1 ppm range, which range is especially of interest in naturally ventilated cattle barns. For application in practice it is important to monitor the sensor performance and the stability of calibration lines on long term under barn conditions and also its performance at higher concentration levels.

Therefore it is recommended to test the Draeger sensor in a field study. A field study could include:

- Measurements inside a natural ventilated dairy house, combined with $\mathrm{CO}_{2}$ measurements for estimation of the ventilation rate;

- Measurements of the ammonia concentration levels inside a pig or poultry house;

- Measurements of the ammonia removal efficiency of a scrubber operated at a pig house. 


\section{Appendix A - Certificate of $11.0 \mathrm{ppm} \mathrm{NH}$ gas cylinder}

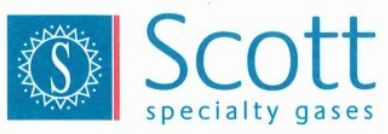

CUSTOM CLASS

Takkebijsters 484817 BL, Breda, The Netherlands Phone:+31(0)76-5711 828 Fax:+31(0)76-5713 267

CERTIFICATE OF ACCURACY: Custom Class Calibration Standard

Product Information

Project No.: 20-97567-002

Item No.: 20020000150Z50L

P.O. No.: WUR728325

Cylinder Number: 5902857

Cylinder Size: 50L

Certification Date: 05May2014

Expiration Date: 04May2015

\section{CERTIFIED CONCENTRATION}

Component Name

AMMONIA

NITROGEN

TRACEABILITY

Description

ANALYTICAL TRACEABILITY

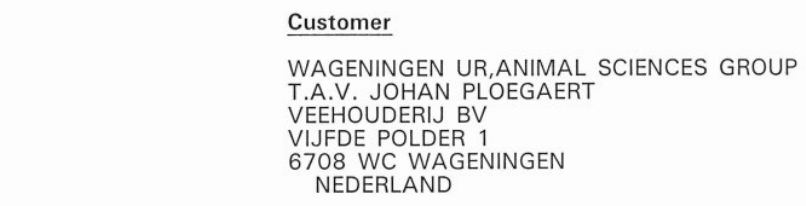

Concentration (Moles)

11,0 PPM BALANCE

\section{Accuracy \\ $(+1-\%)$}

3

Traceability Type GAS STANDARDS
Traceable To

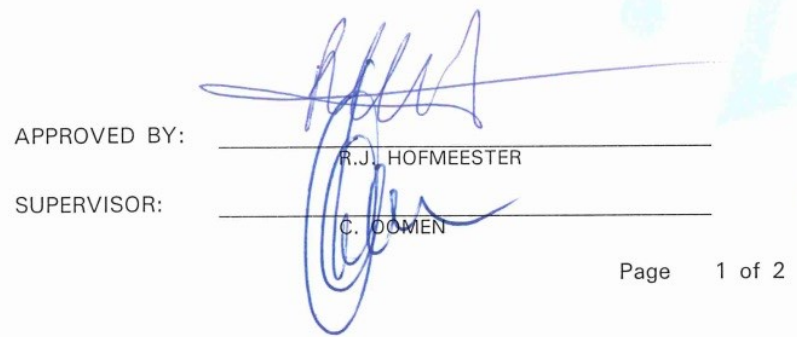

DATE: $14-05-2014$ 


\begin{tabular}{|c|c|c|c|c|c|c|c|}
\hline SPECIFICATIONS & $\begin{array}{l}\text { Requested } \\
\text { Concentration } \\
\text { (Moles) }\end{array}$ & $\begin{array}{l}\text { Gravimetric } \\
\text { Concentration } \\
\text { (Moles) }\end{array}$ & $\begin{array}{c}\text { Analyzed } \\
\text { Concentration } \\
\text { (Moles) }\end{array}$ & $\begin{array}{c}\text { Blend } \\
\text { Tolerance } \\
\text { Result } \\
(+/-\%)\end{array}$ & $\begin{array}{c}\text { Blend } \\
\text { Process } \\
\text { Accuracy } \\
\text { Result } \\
(+1-\%)\end{array}$ & $\begin{array}{c}\text { Analytical } \\
\text { Accuracy } \\
\text { Result } \\
(+1-\%)\end{array}$ & $\begin{array}{l}\text { Interlocking } \\
\text { Result } \\
(+/-\%)\end{array}$ \\
\hline $\begin{array}{l}\text { AMMONIA } \\
\text { NITROGEN }\end{array}$ & 10, & $\mathrm{~N} / \mathrm{A}$ & 11,0 & 10,0 & $\mathrm{~N} / \mathrm{A}$ & 3,00 & $\mathrm{~N} / \mathrm{A}$ \\
\hline
\end{tabular}

\section{TRACEABILITY}

Analytical Traceability

\begin{tabular}{|c|c|c|c|c|}
\hline$\frac{\text { Type/SRM No. }}{\text { SRS TSTD }}$ & $\frac{\text { Expiration Date }}{\text { 05May2014 }}$ & Cylinder Number & $\frac{\text { Concentration }}{0,000}$ & Component \\
\hline \multicolumn{5}{|c|}{ PHYSICAL PROPERTIES } \\
\hline Cylinder Size: & $50 \mathrm{~L}$ & $\begin{array}{l}\text { Pressure: } \\
\text { Expiration Date: }\end{array}$ & $\begin{array}{l}150 \text { BAR } \\
\text { 04May2015 }\end{array}$ & Valve Connection: \\
\hline
\end{tabular}

\section{SPECIAL HANDLING INSTRUCTIONS}

Do not use or store cylinder at or below the stated dew point temperature. Possible condensation of heavier components could result. In the event the cylinder has been exposed to temperatures at or below the dew point, place cylinder in heated area for 24 hours and then roll cylinder for 15 minutes to re-mix.

Use of calibration standards at or below dew point temperature may result in calibration error. 


\section{Appendix $\mathrm{B}$ - Certificate of $101 \mathrm{ppm} \mathrm{NH}$ gas cylinder}

\section{CUSTOM CLASS}

Takkebijsters 484817 BL, Breda, The Netherlands Phone:+31(0)76-5711 828 Fax:+31(0)76-5713 267

\section{CERTIFICATE OF ACCURACY: Custom Class Calibration Standard}

Product Information

Project No.: 20-01957-002

Item No.: 20020000150Z50L

P.O. No.: WUR837436

Cylinder Number: 5902919

Cylinder Size: 50L

Certification Date: 30Apr2015

Expiration Date: 29Apr2018

\section{CERTIFIED CONCENTRATION}

Component Name

AMMONIA

NITROGEN

\section{TRACEABILITY}

\section{Description}

ANALYTICAL TRACEABILITY
Concentration (Moles)

101, PPM BALANCE

Traceability Type

GAS STANDARDS

\section{Customer}

WAGENINGEN UR, ANIMAL SCIENCES GROUP ATTN: JOHAN PLOEGAERT

VEEHOUDERIJ BV, ZODIAC

GEBOUW 122, DE ELST 1
6708 WD WAGENINGEN

NEDERLAND

\section{Accuracy}

$(+1-\%)$

1

1

Traceable To

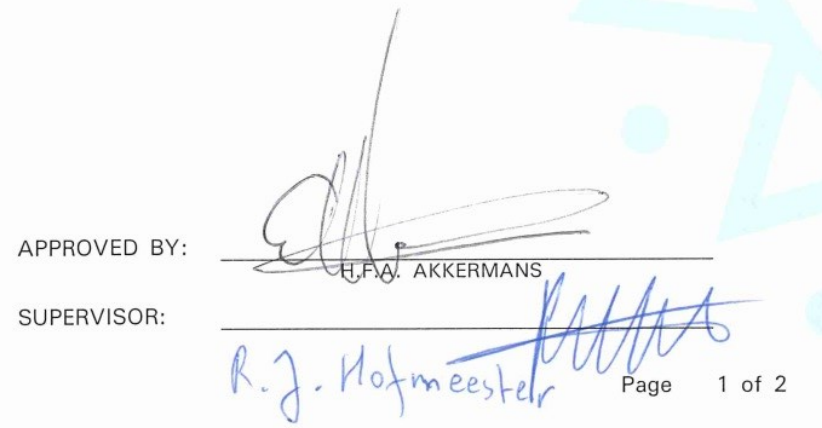

Date: $01-05-2015$ 


\begin{tabular}{|c|c|c|c|c|c|c|c|}
\hline SPECIFICATIONS & $\begin{array}{c}\text { Requested } \\
\text { Concentration } \\
\text { (Moles) }\end{array}$ & $\begin{array}{l}\text { Gravimetric } \\
\text { Concentration } \\
\text { (Moles) }\end{array}$ & $\begin{array}{c}\text { Analyzed } \\
\text { Concentration } \\
\text { (Moles) }\end{array}$ & $\begin{array}{c}\text { Blend } \\
\text { Tolerance } \\
\text { Result } \\
(+1-\%)\end{array}$ & $\begin{array}{c}\text { Blend } \\
\text { Process } \\
\text { Accuracy } \\
\text { Result } \\
(+/-\%)\end{array}$ & $\begin{array}{c}\text { Analytical } \\
\text { Accuracy } \\
\text { Result } \\
(+/-\%)\end{array}$ & $\begin{array}{l}\text { Interlocking } \\
\text { Result } \\
(+/-\%)\end{array}$ \\
\hline $\begin{array}{l}\text { AMMONIA } \\
\text { NITROGEN }\end{array}$ & 100, & $\mathrm{~N} / \mathrm{A}$ & 101, & 1,0 & $\mathrm{~N} / \mathrm{A}$ & 1,00 & N/A \\
\hline
\end{tabular}

\section{TRACEABILITY}

Analytical Traceability

\begin{tabular}{|c|c|c|c|c|}
\hline$\frac{\text { Type/SRM No. }}{\text { SRS TSTD }}$ & $\frac{\text { Expiration Date }}{30 \mathrm{Apr} 2015}$ & Cylinder Number & $\frac{\text { Concentration }}{0,000}$ & Component \\
\hline \multicolumn{5}{|c|}{ PHYSICAL PROPERTIES } \\
\hline Cylinder Size: & $50 \mathrm{~L}$ & $\begin{array}{l}\text { Pressure: } \\
\text { Expiration Date: }\end{array}$ & $\begin{array}{l}\text { 150 BAR } \\
29 \mathrm{Apr} 2018\end{array}$ & Valve Connection: DIN 5 \\
\hline
\end{tabular}

SPECIAL HANDLING INSTRUCTIONS

If a dew point is listed, do not use or store cylinder at or below the stated dew point temperature. Possible condensation of heavier components could result. In the event the cylinder has been exposed to temperatures at or below the dew point, place the cylinder in heated area for 24 hours and then roll cylinder for 15 minutes to remix.

Use of calibration standards at or below the stated dew point temperature may result in calibration error. 


\section{Appendix C - Certificates of Signal 821 diluter}

2015:

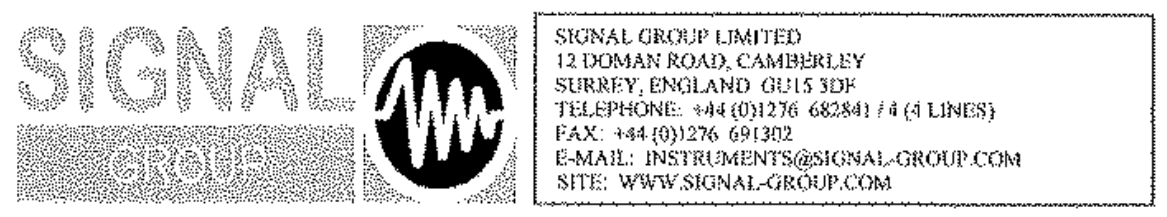

\section{CERTIFICATE OF CALIBRATION}

CONSIGNES

Wagentintgen

ORDFR NUMBER

W/O NUMBER

DATE OF CALIRRATION $01 / 2 / 2015$

\begin{tabular}{|c|c|c|}
\hline DESCRIPTION OF GOODS & SERIAL NO. & REMARKS \\
\hline \$21S gas divider & 4789 & \\
\hline
\end{tabular}

\section{CALIBRATION RESULTS}

\begin{tabular}{|c|c|}
\hline DIVIIJER SETTING & ACTUAL RESULT \\
\hline $106,10 \%$ & 100.00 \\
\hline $90.00 \%$ & 96.99 \\
\hline $80 .(3901 / 4$ & 79.92 \\
\hline $70 .(10 \%$ & 69.93 \\
\hline $60,019 \%$ & 60,04 \\
\hline $50,60 \%$ & 50.96 \\
\hline $40,10 \%$ & 39.90 \\
\hline $30,66 \%$ & 30.02 \\
\hline $20.00 \%$ & 20.08 \\
\hline $10.101 \%$ & 10.12 \\
\hline $0.613 \%$ & 0,00 \\
\hline
\end{tabular}

CALIBRATION GASDETALS

\begin{tabular}{|c|c|c|c|}
\hline CALIBRATION GASTYPE & SUPPLER & CERTUICATE Na & TRACEABLITY \\
\hline (1)0lppen C3H8/atr & $\mathrm{BOC}$ & 1433495 & $\mathrm{NPI}$ \\
\hline
\end{tabular}

SIONAL AUDIT PROCEDURE NUMEER TPBo0101

UNCERTAINTY OH MEASUREMENT $+1-0.2 \%$ E.S.D.

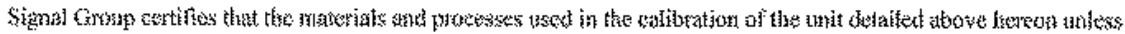

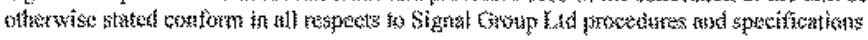

SIGNED Roy Kinslow 


\section{5:}

\section{CERTIFICATE OF CALIBRATION}

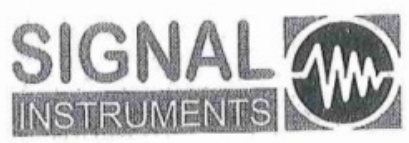

STANDARDS HOUSE,

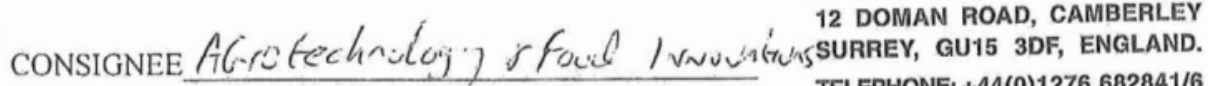
TELEPHONE: $+44(0) 1276682841 / 6$ ORDER NUMBER FACSIMILE: $+44(0) 1276691302$ EMAlL: instruments@signal-group.com W/O NUMBER

DATE OF CALIBRATION $14 / 10 / 05$

\begin{tabular}{|c|l|l|}
\hline DESCRIPTION OF GOODS & SERIAL No & REMARKS \\
\hline 82 is iAs Divide. & 4789 & \\
\hline
\end{tabular}

\section{CALIBRATION RESULTS}

\begin{tabular}{|c|c|c|}
\hline DIVIDER SETTING & EXPECTED RESULT & ACTUAL RESULT \\
\hline $100.00 \%$ & & 10000 \\
\hline $90.00 \%$ & & $8 \% .42$ \\
\hline $80.00 \%$ & & $7 \% .82$ \\
\hline $70.00 \%$ & $=$ & 64.81 \\
\hline $60.00 \%$ & & $5 \% .85$ \\
\hline $50.00 \%$ & & 50.03 \\
\hline $40.00 \%$ & & $3 \% .85$ \\
\hline $30.00 \%$ & & $30 \cdot 01$ \\
\hline $20.00 \%$ & & $20.0 i$ \\
\hline $10.00 \%$ & & 10.07 \\
\hline $0.00 \%$ & & $\left(C^{\prime} \cdot()\right.$ \\
\hline
\end{tabular}

CALIBRATION GAS DETAILS

\begin{tabular}{|c|c|c|c|}
\hline CALIBRATION GAS TYPE & SUPPLIER & CERTIFICATE No. & TRACEABILITY \\
\hline loxplp carll lain & Messe- & 1114023 & VPL \\
\hline
\end{tabular}

SIGNAL AUDIT PROCEDURE NUMBER TFBOC' $(1)$

UNCERTAINTY OF MEASUREMENT $+1-0.2 \%, f \cdot s \cdot \mathrm{l}^{2}$

Signal Group certifies that the materials and processes used in the calibration of the unit detailed above hereen unless otherwise stated conform in all respects to Signal Group Ltd procedures and specifications.

SIGNED

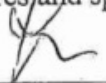




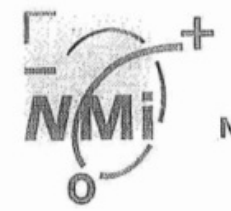

Nederlands Meetinstituut
Certificat

QUD
Nummer 316430-01

blad 1 van 2

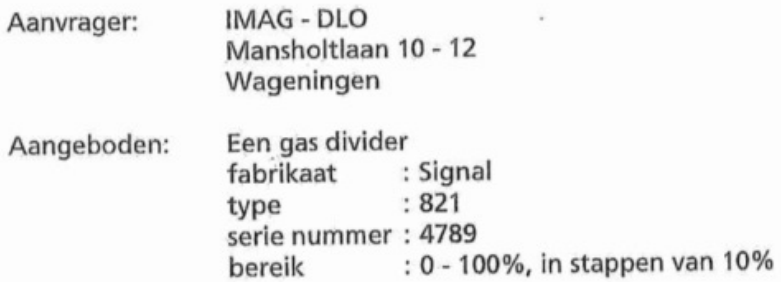

Wijze van De door de gas divider gemaakte verdunningen zijn onderzocht met een referenonderzoek: tiemonitor welke gekalibreerd is met primaire standaard gasmengsels. Als nulgas is hoogzuivere stikstof aangeboden aan de gas divider. Als spangas is een mengsel gebruikt van $(1001 \pm 10) \cdot 10^{-6} \mathrm{~mol} / \mathrm{mol}$ stikstofmonoxide in stikstof. Bepaald is het werkelijke verdunningspercentage. De metingen werden uitgevoerd bij een omgevingstemperatuur van $21 \pm 0,5^{\circ} \mathrm{C}$.

Datum van $\quad 6$ tot en met 20 september 1996

onderzoek:

De resultaten staan vermeld op blad 2 van 2 .

De totale meetonzekerheid is gebaseerd op twee maal de standaardafwijking (2s).

Herleidbaar- De bij de kalibratie gebruikte gasmengsels zijn herleidbaar naar de primaire heid: standaard gasmengsels stikstofmonoxide in stikstof.

Datum en on- 24 september 1996 dertekening: NMi Van Squinden Laboratorium B.V.

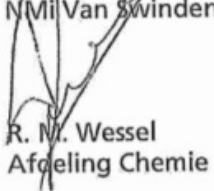

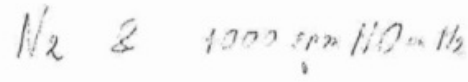

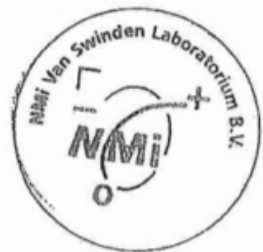

Nederlands Meetinstituut Postbus 654

2600 AR Delft (NL)

Schoemakerstraat 97 2628 VIK Delft

Telefoon (015) 2691500 Telefax (015) 2612971
Nederlands Meetinstituut N.V. (Ingeschreven bil) de Kamer van Koophandel Delft onder nummer 28701 Werkmaatschappijen:

NMM Certin B.V. (KVK nr. 33418) B.V. (KVK nr. 28700) NMi International B.V. (KVK nr. 39176)
Dit certificaat wordt verstrekt onder het voorbehoud dat generlel aansprakelijkheid wordt aanvaard en dat
aanvrager vrij|waring geeft voor elke aansprakelijkheid jegens derden.

Reproduktie van het volledige certificaat is toegestaan. Gedeelten van dit certificaat mogen slechits worden gefeproduceerd na verkregen schriftelijke toestemming. 


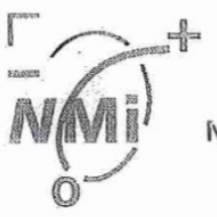

Nederlands IMeetinstituut

Nummer 316430-01

blad 2 van 2

Resultaat: Hieronder wordt het resultaat van de kalibratie weergegeven

Meetbereik $0-100 \%$ in stappen van $10 \%$.

\begin{tabular}{|c|c|}
\hline $\begin{array}{c}\text { Werkelijk verdunnings- } \\
\text { percentage }(\%)\end{array}$ & $\begin{array}{c}\text { ingesteld verdunnings } \\
\text { percentage }(\%)\end{array}$ \\
\hline \hline $10,05 \pm 0,10$ & 10 \\
$19,91 \pm 0,12$ & 20 \\
$29,86 \pm 0,12$ & 30 \\
$39,73 \pm 0,18$ & 40 \\
$49,93 \pm 0,20$ & 50 \\
$60,04 \pm 0,25$ & 60 \\
$69,88 \pm 0,25$ & 70 \\
$79,95 \pm 0,25$ & 80 \\
$89,99 \pm 0,25$ & 90 \\
\hline
\end{tabular}

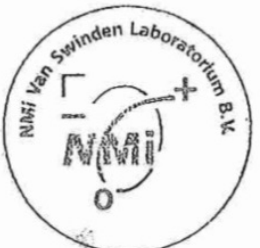




\section{Appendix D - Certificate of EPM 797-430 diluter}

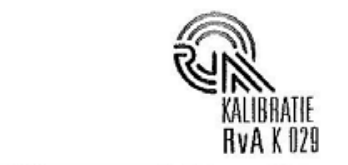

Kalibratie-certificaat c02009-3

$\begin{aligned} \text { Aanvrager: } & \begin{array}{l}\text { ASG Veehouderii B.V. } \\ \text { Postbus } 65 \\ \\ 8200 \mathrm{AB} \text { Lelystad }\end{array} \\ \text { Aangeboden: } & \text { Laboratoriumverdunner } \\ \text { Fabrikaat } & \text { EPM } \\ \text { Type } & 797.430 \\ \text { Serienummer } & \text { E } 77\end{aligned}$

Wijze van onderzoek:

Het onderzoek werd uitgevoerd met $\mathrm{CO}$ als tracergas. De CO-concentraties werden gemeten met een gekalibreerde GFC CO-analyser. De verdunningen werden berekend uit de in en uitgaande CO-gasconcentraties van het verdunningstoestel.

Omgevingscondities Het onderzoek is uitgevoerd bij een ruimtetemperatuur van $(21 \pm 2)^{\circ} \mathrm{C}$.

Datum van onderzoek: 17 maart 2009.

Resultaat: De resultaten en meetonzekerheden staan vermeld op blad 2.

Onzekerheid: De gerapporteerde onzekerheid is gebaseerd op de standaardonzekerheid vermenigvuldigd met een dekkingsfactor $k=2$, welke overeenkomt met een betrouwbaarheidsinterval van ongeveer $95 \%$. De standaardonzekerheid is bepaald volgens EA-4/02.

Herleidbaarheid: De metingen zijn uitgevoerd met meetmiddelen waarvan de herleidbaarheid naar (inter)nationale standaarden is aangetoond ten overstaan van de Raad voor Accreditatie.

Datum en

Wageningen, 26 maart 2009

ondertekening:

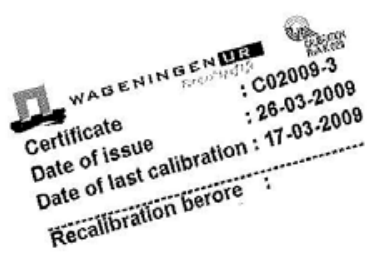

Ing. J.P.M. Ploegaert

Coördinator Geurlaboratorium

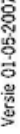

Wageningen UR ASG Veehouderii B.V. uster MHE Wageningen

Bornsesteeg 59 6708 PD Wageningen Telefoon $+31(0) 317487276$ Telefax +31 (0) 317475347
Reproductie van het volledige certificaat is toegestaan. Gedeelten mogen slechts worden gereproduceerd na schriftelijke toestemming van ASG Veehouderij.

Dit certificaat wordt verstrekt onder de voorwaarde dat ASG Veehouderii generlei aansprakelijkheid aanvaardt. 


\section{Kalibratie-certificaat} c02009-3

\begin{tabular}{cccccc}
\hline Instelling & Verdunning & & $\begin{array}{c}\text { Onzekerheid } \\
(\mathrm{k}=2) \\
{[-]}\end{array}$ & $\begin{array}{c}\text { Nauwkeurig- } \\
\text { heid } \\
{[-]}\end{array}$ & $\begin{array}{c}\text { Stabiliteit } \\
\%\end{array}$ \\
\hline 2.6 & 10.0 & $+/-$ & 0.03 & 0.008 & 0.24 \\
3.0 & 11.0 & $+/-$ & 0.01 & 0.008 & 0.28 \\
4.0 & 13.5 & $+/-$ & 0.06 & 0.005 & 0.22 \\
5.0 & 16.0 & $+/-$ & 0.08 & 0.004 & 0.19 \\
6.0 & 18.7 & $+/-$ & 0.15 & 0.003 & 0.23
\end{tabular}

Opmerkingen: Metingen conform NEN-EN 13725:2003. Uitgevoerd door JP. De laboratoriumverdunner werd met de hand bediend.

Reproductie van het volledige certificaat is toegestaan. Gedeelten mogen slechts worden gereproduceerd na chriftelijke toestemming van ASG Veehouderii.

6708 PD Wageninge

Dit certificaat wordt verstrekt onder de voorwaarde dat ASG Veehouderij generlei aansprakelijkheid aanvaardt. 

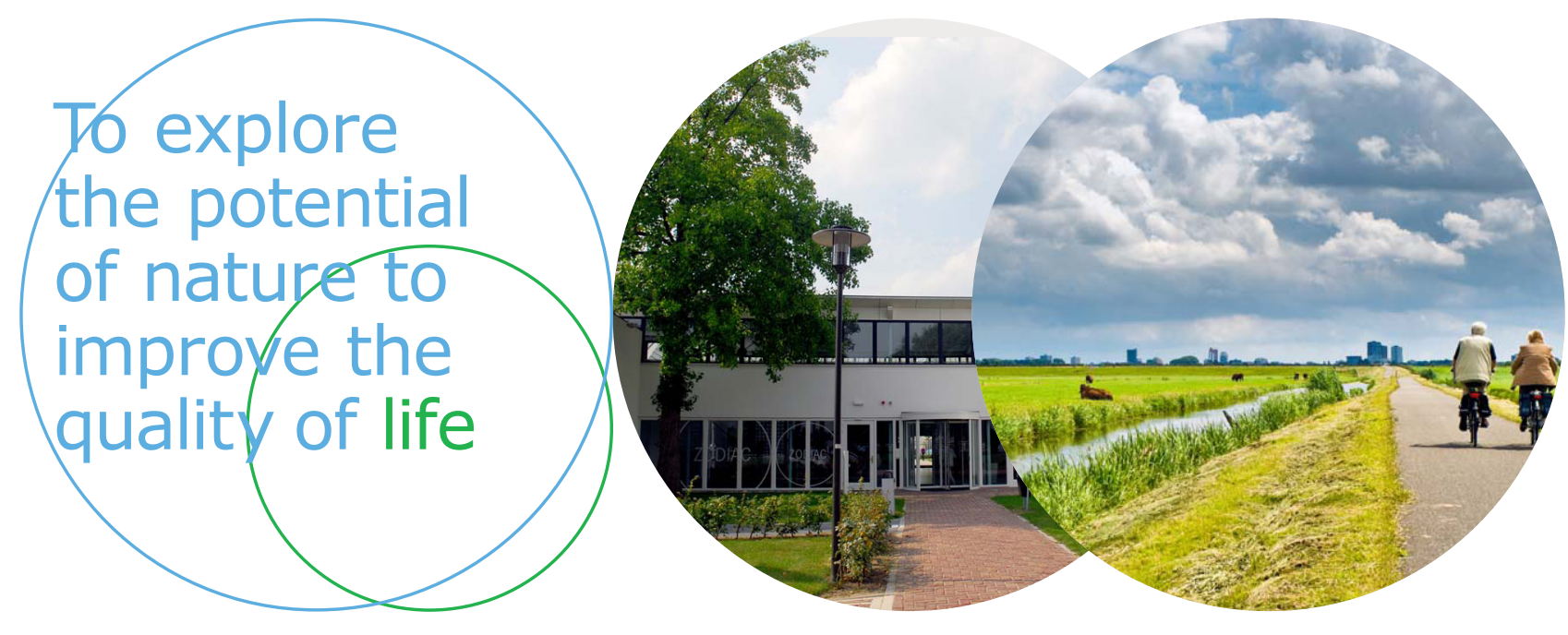

Wageningen UR Livestock Research

P.O. Box 338

6700 AH Wageningen

The Netherlands

T+31 (0)317483953

E info.livestockresearch@wur.nl

www.wageningenUR.nl/livestockresearch
Together with our clients, we integrate scientific know-how and practical experience to develop livestock concepts for the 21st century. With our expertise on innovative livestock systems, nutrition, welfare, genetics and environmental impact of livestock farming and our state-of-the art research facilities, such as Dairy Campus and Swine Innovation Centre Sterksel, we support our customers to find solutions for current and future challenges.

The mission of Wageningen UR (University \& Research centre) is 'To explore the potential of nature to improve the quality of life'. Within Wageningen UR, nine specialised research institutes of the DLO Foundation have joined forces with Wageningen University to help answer the most important questions in the domain of healthy food and living environment. With approximately 30 locations, 6,000 members of staff and 10,000 students, Wageningen UR is one of the leading organisations in its domain worldwide. The integral approach to problems and the cooperation between the various disciplines are at the heart of the unique Wageningen Approach. 